\title{
Fenomena Gender dalam Dongkari Lagu-Lagu Tembang Sunda Cianjuran ${ }^{1}$
}

\author{
Deni Hermawan \\ Sekolah Tinggi Seni Indonesia (STSI) Bandung \\ Jl. Buah Batu No. 212 Bandung 40265
}

\begin{abstract}
This article, "Gender Fenomena in Dongkari of Tembang sunda cianjuran Songs," is a small part of my dissertation entitled "Gender dalam Tembang sunda cianjuran," which is then elaborated in accordance with the theme of this article. This article is intended to study gender fenomena in one of a number of aspects of Tembang sunda cianjuran, dongkari. How far gender ideology in social life affects the performance of Tembang sunda cianjuran, especially in using dongkari in Tembang sunda cianjuran songs, and vise versa.From this study, it is obtained a conclusion asserting that gender fenomena can be found in dongkari. This are shown by the existence of masculine and feminine ornament/dongkari which are each usually used by men and women singers in singing the Tembang sunda cianjuran songs. However, this can not be free from cross-gender fenomena which always participate in it so that in certain cases, masculine ornamnet/dongkari can be used by women singers, and vise versa. The relationship between gender fenomena found in ornament/dongkari and its using by men and women singers in performance of Tembang sunda cianjuran shows mutual relationship and influence between both the gender ideology which is embedded in the Sundanese life and the perfomance of music - Tembang sunda cianjuran.
\end{abstract}

Keywords: gender, Tembang sunda cianjuran, ornamen/dongkari

\begin{abstract}
ABSTRAK
Tulisan ini, "Fenomena Gender dalam Dongkari Lagu-lagu Tembang Sunda Cainjuran," merupakan bagian kecil dari disertasi penulis berjudul "Gender dalam Tembang Sunda Cianjuran," yang kemudian diolah kembali sesuai dengan tema tulisan ini. Tulisan ini bermaksud untuk mengkaji fenomena gender dalam salah satu unsur tembang sunda cianjuran tersebut, yaitu dongkari. Sejauh mana ideologi gender dalam kehidupan masyarakat berpengaruh terhadap pertunjukan tembang sunda cianjuran, khususnya dalam menggunakan dongkari lagu-lagu tembang sunda cianjuran; dan sebaliknya. Dari kajian tersebut diperoleh kesimpulan yang menyatakan bahwa fenomena gender dapat ditemukan dalam ornamen/ dongkari. Hal ini ditunjukkan oleh adanya ornamen/dongkari yang bersifat maskulin dan feminin yang masing-masing biasa digunakan oleh penembang pria dan wanita dalam menembangkan lagu-lagu tembang sunda cianjuran. Kendatipun demikian, hal tersebut tidak terlepas dari fenomena cross-gender yang senantiasa hadir menyertainya sehingga dalam kasus-kasus tertentu, ornamen/dongkari yang bersifat maskulin bisa pula digunakan oleh penembang wanita; dan demikian pula sebaliknya. Keterkaitan antara fenomena gender yang ditemukan dalam ornamen/dongkari dan penggunaannya oleh penembang pria dan wanita dalam praktik pertunjukan tembang sunda cianjuran menunjukkan adanya saling keterkaitan dan saling memengaruhi antara ideologi gender yang melekat dalam kehidupan masyarakat Sunda dan pertunjukan musik-tembang sunda cianjuran.
\end{abstract}

Kata kunci: gender, tembang sunda cianjuran, ornamen/dongkari 


\section{PENDAHULUAN}

Tembang sunda cianjuran adalah salah satu jenis kesenian Sunda klasik berbentuk vokal-instrumental yang lahir di Cianjur, Jawa Barat. Oleh sebab itulah kesenian ini dinamakan 'cianjuran', yang mengandung pengertian 'tembang Sunda gaya Cianjur'. Jadi, kata 'cianjuran' di sini tidak hanya menunjukkan daerah asalnya, tetapi juga sekaligus menunjukkan gaya (versi)-nya yang berbeda dari gaya (versi) seni tembang dari daerah lainnya, yaitu ciawian yang berasal dari Ciawi-Tasikmalaya dan cigawiran yang berasal dari Limbangan-Garut.

Sebagai kesenian berbentuk vokal-instrumental, Tembang sunda cianjuran terdiri dari dua unsur, yaitu vokal (lagu) yang dibawakan oleh penembang (pria dan wanita) dan instrumental (bunyi alat musik) yang dimainkan pada seperangkat alat musik terdiri dari kacapi (kacapi indung dan kacapi rincik) dan suling atau rebab. ${ }^{2}$ Di antara kedua unsur tersebut, vokal (lagu) merupakan unsur pokok dalam Tembang sunda cianjuran. Dalam lagu ini pun terkandung beberapa unsur yang menentukan nilai keindahan (nilai estetik) dari lagu tersebut, salah satu di antaranya dan yang paling utama adalah hiasan lagu atau ornamen yang dibentuk oleh rangkaian dongkari. ${ }^{3}$

Salah satu fenomena menarik dan penting dalam Tembang sunda cianjuran adalah gender (baca: /jénder/), yaitu hubungan gender yang terjadi antara yang dipersepsikan sebagai maskulin dan feminin. Gender, yang secara sederhana diartikan sebagai perbedaan peran antara wanita dan pria yang dibentuk secara sosial/kultural, senantiasa hadir dan melekat dalam berbagai aktivitas atau peristiwa kehidupan manusia, salah satunya adalah dalam aktivitas musikal, khusunya dalam pertunjukan musik, seperti Tembang sunda cianjuran.

Ideologi gender dalam kehidupan masyarakat memiliki pengaruh yang sangat kuat terhadap Tembang sunda cianjuran. Demikian pula sebaliknya. Kenyataan saling memengaruhi ini-antara gender dan musik-sejalan dengan pernyataan konseptual/teoretis yang dikemukakan oleh Koskoff (1987: 10) dalam bentuk pertanyaan: (1) sampai pada tingkatan mana ideologi gender dari satu masyarakat dan perilaku yang berkaitan dengan gender yang dihasilkan memengaruhi pikiran dan praktik musik; dan (2) bagaimana musik berfungsi di masyarakat untuk mencerminkan atau memengaruhi hubungan gender.

Moore (1991:13) mengemukakan bahwa gender bisa dilihat sebagai satu konstruksi simbolik atau sebagai satu hubungan sosial. Demikian pula halnya dengan gender dalam musik seperti Tembang sunda cianjuran. Sebagai konstruksi simbolik (abstrak), gender tampak pada unsur-unsur Tembang sunda cianjuran, dalam bentuk hubungan gender antara "pria" dan "wanita" dalam rumpaka lagu, lagu, dongkari, dan alat musik; sedangkan sebagai suatu hubungan sosial (konkret), gender tampak pada pemainnya, dalam bentuk hubungan gender antara penembang wanita dan penembang pria, dan antara penembang wanita dan pemain alat musik yang terdiri atas pria.

Tulisan ini bermaksud untuk mengkaji fenomena gender dalam salah satu dari kelima unsur Tembang sunda cianjuran tersebut, yaitu dongkari. Sejauh mana ideologi gender dalam kehidupan masyarakat berpengaruh terhadap praktik pertunjukan Tembang sunda cianjuran, khususnya dalam menggunakan dongkari lagu-lagu Tembang sunda cianjuran; dan sebaliknya.

\section{PEMBAHASAN}

\section{Gender dalam Ornamen/Dongkari}

Ornamen dalam Tembang sunda cianjuran merupakan aspek yang sangat penting dan sekaligus merupakan identitas musikal 
yang membedakan seni vokal ini dari seniseni vokal lainnya seperti tembang ciawian, tembang cigawiran, kawih kapasindenan, dan kawih wanda wanyar. Secara sederhana, ornamen diartikan sebagai hiasan lagu, atau lebih tepatnya lagi, hiasan melodi lagu. Dalam karawitan Sunda, selain istilah ornamen dikenal pula istilah senggol atau dongkari dalam Tembang sunda cianjuran, yaitu motif hiasan lagu. Ornamen pada dasarnya merupakan komposisi yang terdiri dari gabungan motif-motif hiasan lagu (senggol/dongkari).

Dalam tembang sunda cianjuran dikenal ada beberapa macam dongkari. Menurut hasil penelitian Elis Rosliani (1998: 42), ada tujuh belas macam dongkari yang ditemukan, yaitu: 1) riak (nn), 2) reureueus $(\Lambda \Lambda \Lambda), 3)$ gibeg (3), 4) kait ( 囚), 5) inghak ( ), 6) jekluk $(\sqrt{ }), 7)$ beulit/rante $(\wp), 8)$ lapis $(\approx), 9)$ gedag $(\mathrm{Z})$,

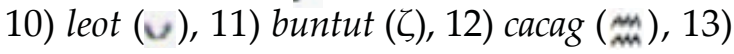
baledog $(\boldsymbol{\nabla}), 14)$ kedet $(\boldsymbol{\partial}), 15)$ dorong $(\rightarrow)$, 16) galasar (3), dan 17) golosor ( $\xi)^{4}$. Selain dari ketujuh belas dongkari tersebut, masih terdapat pula dua dongkari lainnya yang baru-baru ini teridentifikasi, yaitu: 18) ombak $(\Omega \Omega \Omega)$ dan 19) dangheuak $(\Omega)$ sehingga semuanya menjadi sembilan belas dongkari ${ }^{5}$. Berikut adalah uraian tentang kesembilan belas dongkari tersebut.

\section{1) $\operatorname{Riak}(\mathrm{nnn})^{6}$}

Menurut Kamus Umum Basa Sunda, riak artinya nimbulkeun cahaya nu siga ombak-ombakan (menimbulkan cahaya seperti gelombang). Sedangkan menurut Bakang Abubakar, istilah riak sama dengan istilah ombak banyu yang artinya gelombang air (Sarinah, 1994: 121). Adapun teknik penyuaraan dongkari riak yaitu mengeluarkan getaran suara pada nada yang tetap yang menyerupai gelombang air. Getaran suara dikeluarkan tanpa tekanan, tetapi secara halus tanpa terputus. Contoh, nada 5 (la) yang menggunakan dongkari riak artinya nada 5 (la) dibunyikan dengan halus tanpa terputus menyerupai gelombang air. Seba- gai contoh, dongkari riak dalam lagu Papatet baris pertama sebagai berikut:

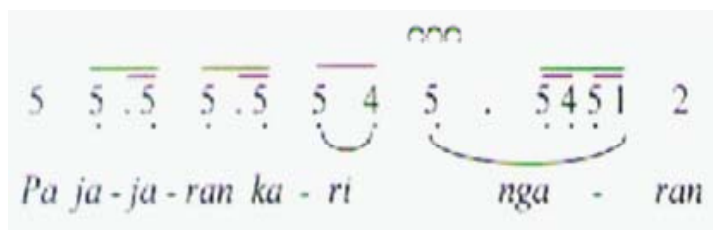

2) Reureueus $(\Lambda \Lambda \Lambda)$

Reureueus pada umumnya digunakan oleh para penembang untuk menamakan semua jenis dongkari dalam Tembang sunda cianjuran. Meskipun demikian, dalam tulisan ini reureueus memiliki pengertian yang berbeda. Reureueus adalah salah satu macam dongkari yang pada prinsipnya sama dengan riak. Sedikit yang membedakannya yaitu teknik penyuaraan pada dongkari riak tidak mendapat tekanan, sedangkan teknik penyuaraan reureueus yaitu getaran suara yang dikeluarkan pada nada yang tetap mendapat tekanan.

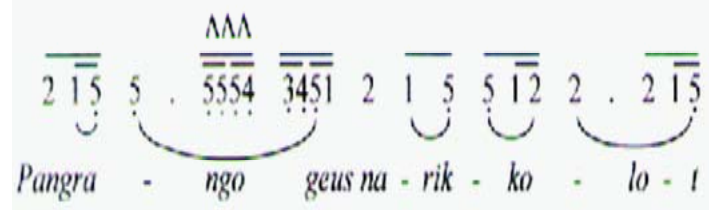

3) Gibeg ( 3 )

Gibeg menurut Kamus Umum Basa Sunda artinya yaitu ngobahkeun awak ka gigir make tanaga sarta rikat (menggerakkan badan ke samping dengan gerak cepat). Teknik penyuaraan dongkari gibeg yaitu mengeluarkan suara pada nada yang tetap disertai tekanan, dan dilakukan dengan gerak cepat seolah-olah digibegkeun.

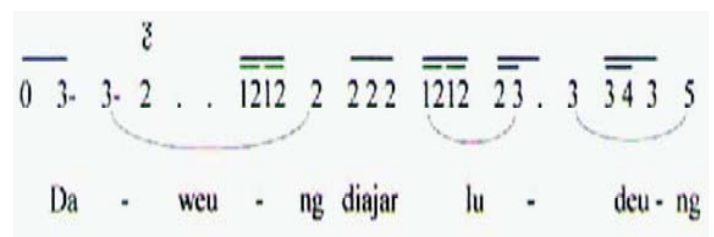

4) Kait ( $(2)$

Kait artinya sama dengan nyangkol yaitu menempel keras karena lilitan tali. Dalam 
istilah dongkari Tembang sunda cianjuran, istilah kait mengandung pengertian gabungan dua buah nada dari nada tinggi ke nada rendah di mana nada pertama dongkari kait menempel/sama dengan nada sebelumnya, kemudian diikuti oleh satu nada yang lebih rendah. Teknik penyuaraannya yaitu bunyi terakhir dari suku kata yang akan diikuti oleh dongkari kait, dibunyikan kembali sebagai jembatan untuk membunyikan suku kata berikutnya.

$$
\begin{aligned}
& \overline{0} \text { 3. 3. 2 . . } \overline{\overline{1212}} 2 \overline{222} \overline{\overline{1212}}=\frac{8}{23}, 3 \overline{\overline{34} 3} 5 \\
& \text { Da - weu - ng diajar lu - deu - ng }
\end{aligned}
$$

\section{5) Inghak ( )}

Istilah inghak diambil dari peristiwa menangis yang diterapkan pada dongkari Tembang sunda cianjuran. Teknik penyuaraannya yaitu pada waktu membunyikan suku kata yang mengandung vokal huruf hidup (a, i, u, e, o) udara sedikit dikeluarkan dengan diberi tekanan sehingga menghasilkan suara yang bunyinya seperti konsonan /h/. Diusahakan posisi bibir tidak bergerak saat mengeluarkan udara.

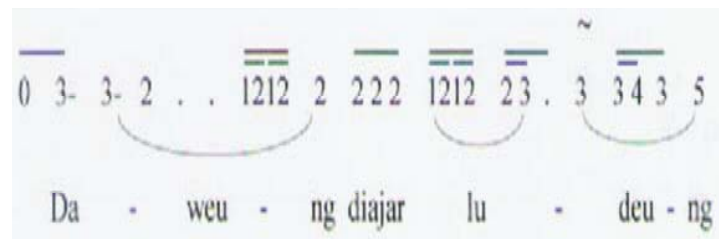

\section{6) Jekluk (V)}

Dongkari jekluk yaitu gabungan dua buah nada dari nada rendah ke nada tinggi. Misalnya dari nada 1 (da) ke nada 5 (la), nada 4 (ti) ke nada 3 (na). Untuk membunyikan dongkari jekluk harus diawali dengan nada yang lebih rendah. Misalnya dari nada 1 (da) ke nada 5 (la), senantiasa diawali dengan nada 2 (mi). Dari nada 4 (ti) ke nada 3 (na), senantiasa diawali dengan nada 5 (la). Teknik penyuaraan dongkari jekluk harus menggunakan tenaga perut.

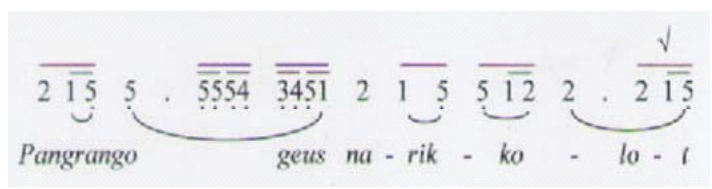

\section{7) Rante ( 8$)$}

Dongkari rante yaitu gabungan dua buah nada atau lebih yang disuarakan dengan cara mengulang nada-nada tersebut sehingga menghasilkan suara yang bila digambarkan menyerupai bentuk spiral atau rante.

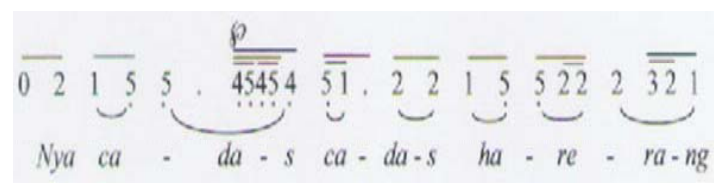

\section{8) Lapis ( $)$}

Dongkari lapis yaitu penyuaraan satu buah nada yang mengikuti nada sebelumnya. Dongkari lapis ini seolah-olah mengulang lagi nada yang sudah dibunyikan oleh dongkari lain.

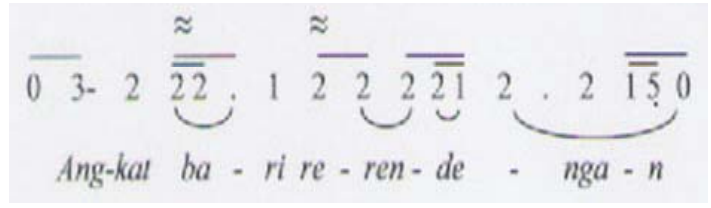

\section{9) Gedag (Z)}

Dongkari gedag yaitu menyuarakan satu nada yang tetap dengan mendapat tekanan. Nada tersebut seolah-olah disuarakan dua kali (diulang). Penempatan ornamen gedag senantiasa di awal kata.

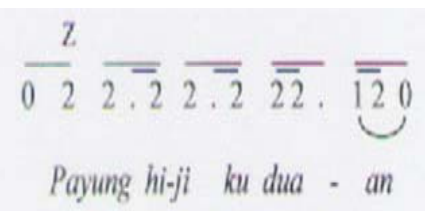

10) Leot ( v )

Dongkari leot yaitu gabungan dua buah nada, dari nada tinggi ke nada rendah, misalnya dari nada 5 (la) ke nada 1 (da), nada 2 (mi) ke 3 (na), dan seterusnya. 


\section{$\overline{02} \overline{2 . \overline{2}} \overline{2 . \overline{2}} \overline{\overline{22}} \cdot \frac{v}{\overline{120}}$ \\ Payung hi-ji ku dua - an}

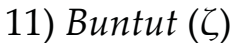

Dongkari buntut pada prinsipnya sama dengan dongkari lapis. Perbedaannya terletak pada penempatannya. Kalau dongkari lapis diletakkan di tengah kata dan senantiasa diikuti lagi dengan dongkari lainnya, sedangkan buntut ditempatkan di akhir kata atau kalimat lagu (frase lagu) dan diikuti oleh satu nada yang lebih tinggi.

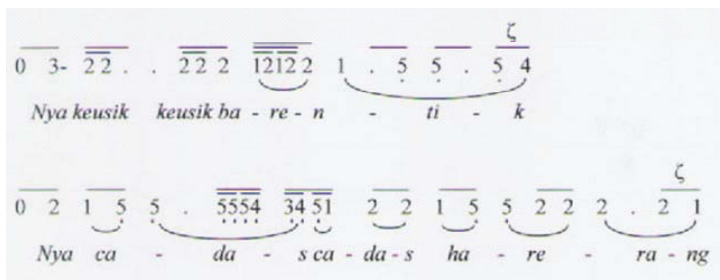

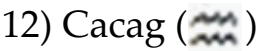

Dongkari cacag yaitu penyuaraan satu buah nada dengan teknik memberikan tekanan pada nada tersebut secara berulang-ulang dan tidak terputus-putus.

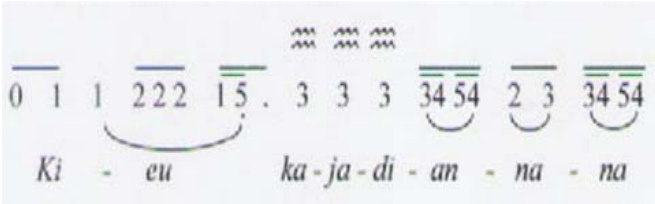

\section{3) Baledog $(\boldsymbol{\nabla})$}

Dongkaribaledog yaitu gabungan dua buah nada yang disuarakan tanpa tekanan. Dongkari ini senantiasa ditempatkan mengikuti ornamen lainnya seperti gibeg dan gedag.

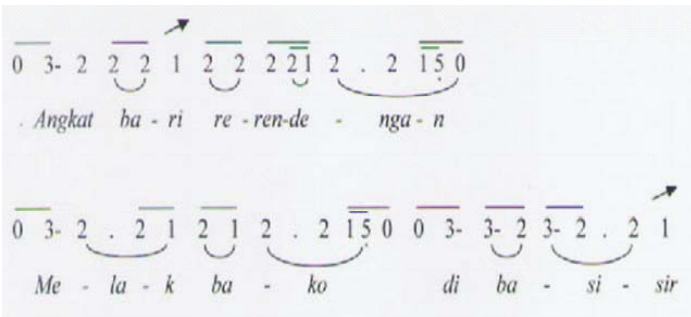

\section{4) Kedet ( ə)}

Dongkari kedet senantiasa ditempatkan di akhir kalimat lagu yang berfungsi untuk $m a-$ dakeun (mengakhiri) lagu. Dongkari ini biasa digunakan dalam lagu wanda jejemplangan.

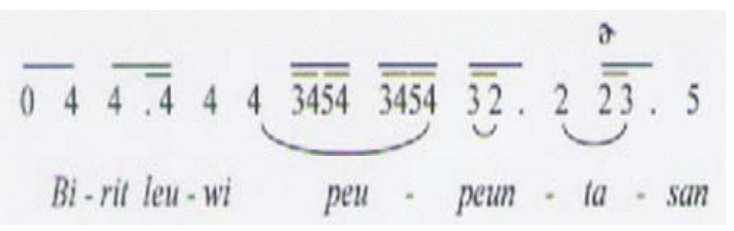

15) Dorong $(\rightarrow)$

Dongkari dorong pada dasarnya merupakan dinamika dari suara yang tidak mendapat tekanan menuju nada berikutnya dengan mendapat tekanan. Biasanya dongkari dorong selalu diikuti oleh reureueus.

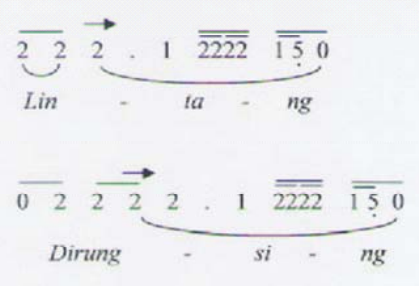

16) Galasar (3)

Dongkari galasar yaitu gabungan dua atau tiga buah nada yang disuarakan seperti diayun, tanpa terputus, dan mendapat tekanan.

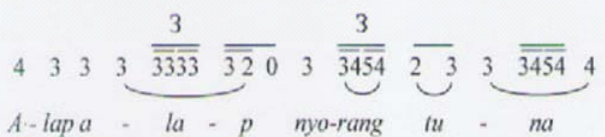

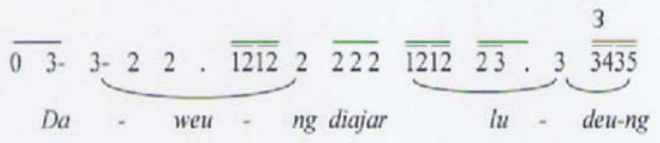

17) Golosor ( $\xi)$

Dongkari golosor yaitu gabungan beberapa nada dengan teknik penyuaraan tanpa tekanan.Wilayah nadanya yaitu dari nada tinggi menuju ke nada rendah. 


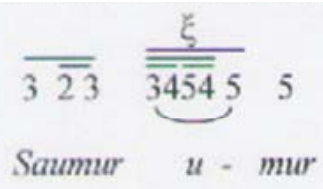

18) Ombak $(\Omega \Omega \Omega)$

Dongkari ombak pada dasarnya sama dengan riak, yaitu mengeluarkan getaran suara pada nada yang tetap yang menyerupai gelombang air. Getaran suara dikeluarkan tanpa tekanan, tetapi secara halus tanpa terputus. Perbedaannya, pada dongkari ombak, getaran suaranya besar-besar (lebih besar daripada getaran suara pada riak) dan dibawakan secara lambat (lebih lambat daripada getaran suara pada riak).

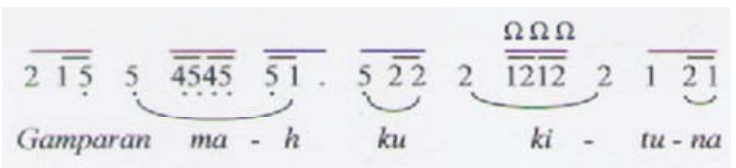

19) Dangheuak ( $\int$ )

Dongkari dangheuak pada dasarnya sama dengan kait, yakni mengandung pengertian gabungan dua buah nada dari nada tinggi ke nada rendah di mana nada pertama dongkari kait menempel/sama dengan nada sebelumnya, kemudian diikuti oleh satu nada yang lebih rendah. Teknik penyuaraannya yaitu bunyi terakhir dari suku kata yang akan diikuti oleh dongkari kait, dibunyikan kembali sebagai jembatan untuk membunyikan suku kata berikutnya. Perbedaannya, dongkari dangheuak disuarakan dengan durasi waktu lebih panjang daripada kait.

$$
\begin{aligned}
& \overline{2 \overline{2}} \quad \overline{2 \overline{22}} \quad \overline{\overline{12} \overline{12}} \quad \overline{\overline{15} \overline{52}} \quad \frac{\{}{\overline{2.123}} \quad 3 \\
& \text { Sok sa - geuy henteu kajudi nu - mawi abdi un - ju - kan }
\end{aligned}
$$

Dari hasil pengamatan terhadap praktik penyajian lagu-lagu Tembang sunda cianjuran, dongkari-dongkari di atas digunakan dalam bentuk rangkaian yang kemudian dikenal sebagai ornamen. Ornamen-ornamen ini ada yang terdiri dari rangkaian dua macam dongkari, tiga macam dongkari, empat macam dongkari, lima macam dongkari, dan enam macam dongkari sebagaimana terlihat pada tabel 1 - 5 .

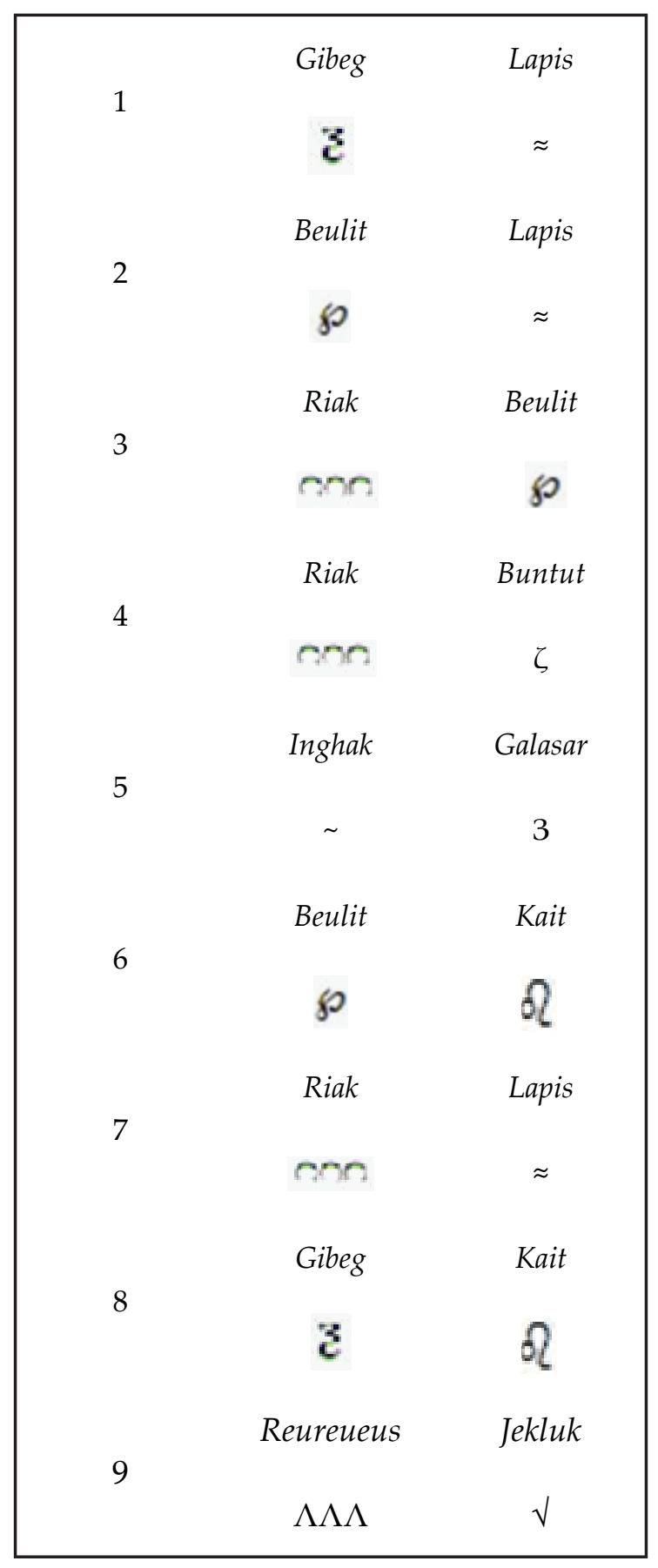

Tabel 1 Ornamen Dua Dongkari 


\begin{tabular}{|c|c|c|c|}
\hline \multirow{2}{*}{1} & Inghak & Gibeg & Lapis \\
\hline & $\sim$ & 3 & $\approx$ \\
\hline \multirow{2}{*}{2} & Riak & Beulit & Kait \\
\hline & mon & 8 & $?$ \\
\hline \multirow{2}{*}{3} & Riak & Gedag & Jekluk \\
\hline & mon & Z & $\sqrt{ }$ \\
\hline \multirow{2}{*}{4} & Riak & Beulit & Lapis \\
\hline & mo & 80 & $\approx$ \\
\hline \multirow{2}{*}{5} & Inghak & Reureueus & Jekluk \\
\hline & $\sim$ & $\Lambda \Lambda \Lambda$ & $\sqrt{ }$ \\
\hline \multirow{2}{*}{6} & Gibeg & Lapis & Riak \\
\hline & 3 & $\approx$ & nn \\
\hline \multirow{2}{*}{7} & Riak & Gedag & Leot \\
\hline & ann & Z & $v$ \\
\hline \multirow{2}{*}{8} & Gibeg & Gibeg & Lapis \\
\hline & 3 & 3 & $\approx$ \\
\hline \multirow{2}{*}{9} & Beulit & Gibeg & Lapis \\
\hline & 8 & 3 & $\approx$ \\
\hline \multirow{2}{*}{10} & Jekluk & Reureueus & Jekluk \\
\hline & $\sqrt{ }$ & $\Lambda \Lambda \Lambda$ & $\sqrt{ }$ \\
\hline \multirow[t]{2}{*}{11} & Beulit & Lapis & Leot \\
\hline & 8 & $\approx$ & $v$ \\
\hline \multirow[t]{2}{*}{12} & Riak & Beulit & Golosor \\
\hline & nn & 80 & $\xi$ \\
\hline
\end{tabular}

Tabel 2

Ornamen Tiga Dongkari

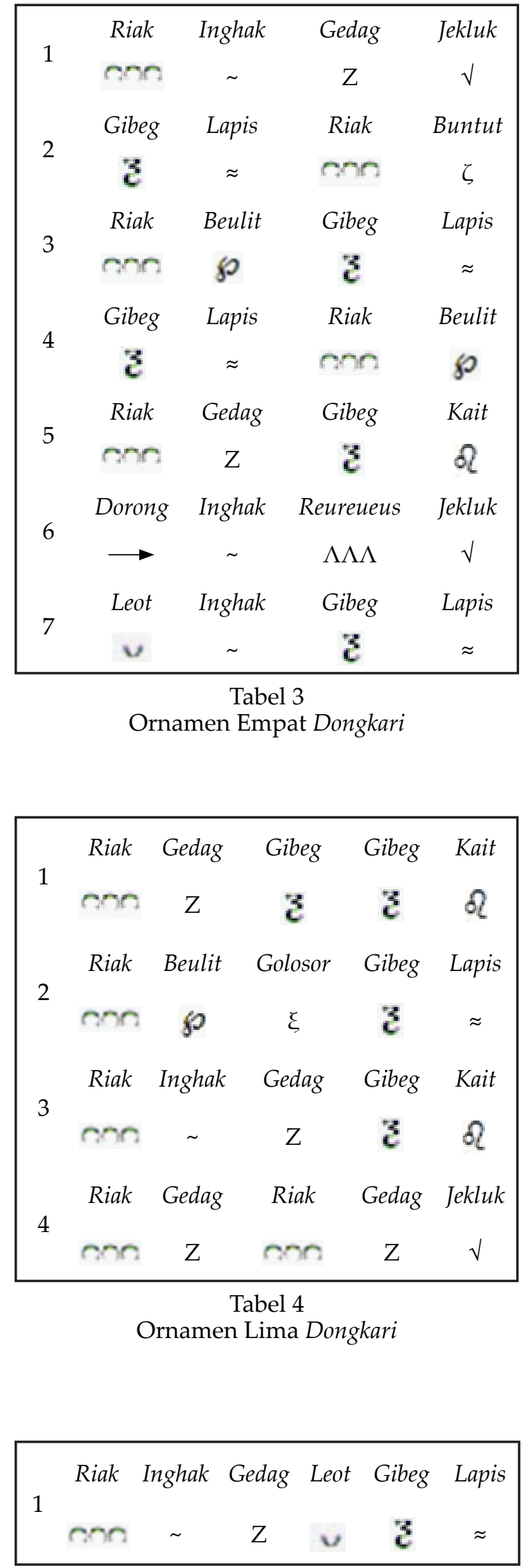

Tabel 5

Ornamen Enam Dongkari 
Fenomena gender dalam ornamen/ dongkari lagu-lagu Tembang sunda cianjuran ditunjukkan dengan adanya ornamen/dongkari yang bersifat maskulin dan feminin. Ornamen/dongkari yang bersifat maskulin lebih umum digunakan oleh penembang pria, sedangkan ornamen/dongkari yang bersifat feminin lebih umum digunakan oleh penembang wanita. Kendatipun demikian, hal tersebut bersifat relatif karena terikat oleh adanya fenomena cross-gender, dalam arti bahwa ornamen/dongkari yang bersifat maskulin bisa juga dibawakan oleh penembang wanita, demikian pula sebaliknya.

Di antara kesembilan belas dongkari yang biasa dipakai dalam penyajian lagulagu Tembang sunda cianjuran, ada dongkari yang bersifat maskulin (laki-laki), ada yang bersifat maskulin/feminin (laki-laki/perempuan), dan yang bersifat feminin (perempuan). Menurut Elis Rosliani (wawancara, 21 November 2012), dongkari yang bersifat maskulin ada satu, yaitu: gedag; yang bersifat feminin ada empat, yaitu: reureueus, inghak, beulit/rante, dan leot; dan yang bersifat maskulin/feminin ada 14, yaitu dongkaridongkari selain yang lima tadi. Untuk lebih jelasnya, lihat tabel 6.

Suatu dongkari diketegorikan sebagai maskulin atau feminin ditunjukkan oleh karakteristik suaranya ketika dongkari tersebut disuarakan (digunakan) dalam penyajian lagu. Dongkari maskulin, ketika disuarakan akan melahirkan kesan atau gambaran sifat perilaku laki-laki seperti gagah, tegas, kuat, tegar, gembira, adapun dongkari feminin, ketika disuarakan akan melahirkan kesan atau gambaran sifat perilaku perempuan seperti halus, lemah, menderita, melankolis, dan sedih.

Dalam penggunaannya, karakteristik dongkari tidak serta-merta bersesuaian dengan jenis kelamin penembangnya. Dongkari yang bersifat maskulin, misalnya, tidak selamanya digunakan oleh penembang pria, tetapi boleh juga digunakan oleh penembang wanita. Demikian pula halnya dengan dong-

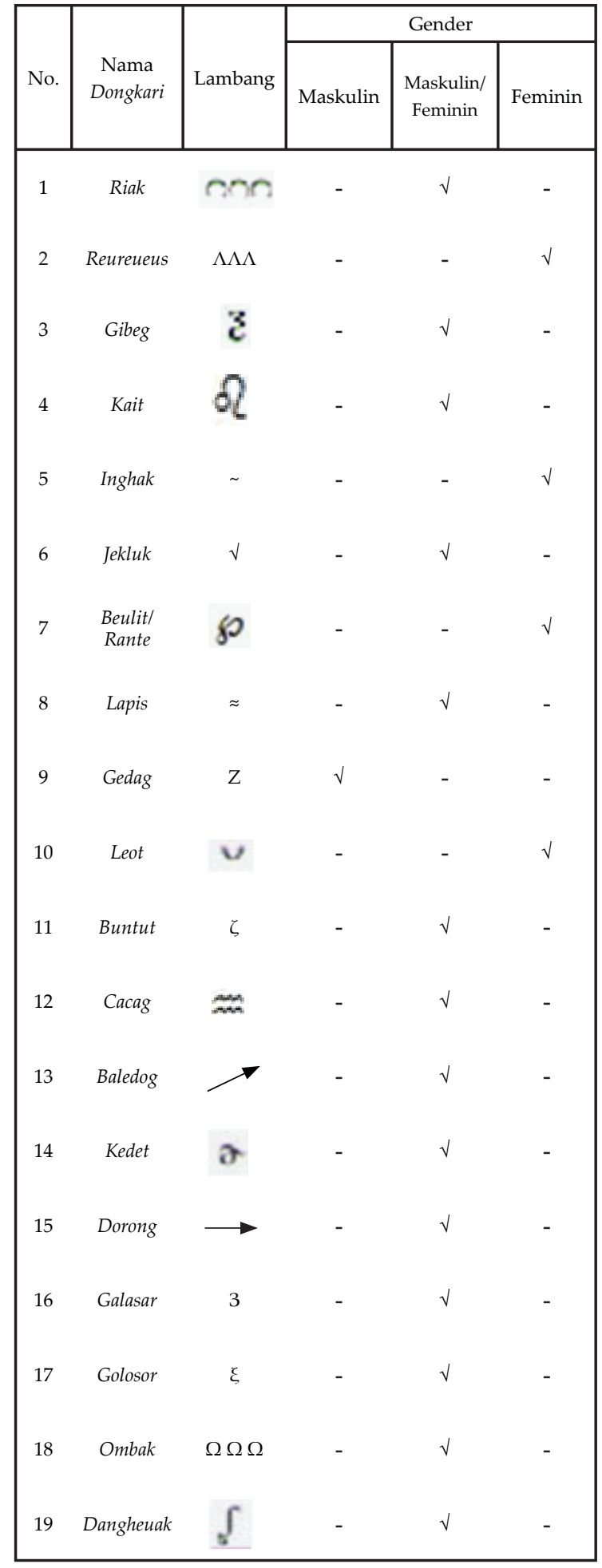

Tabel 6

Gender Dongkari Tembang sunda cianjuran

kari yang bersifat feminin, kadang-kadang digunakan pula oleh penembang pria. Akan tetapi bagi penembang pria yang sudah mengetahui serta memahami karakteristik dongkari, dalam menembangkan lagu-lagu 
cianjuran ia tidak akan menggunakan beulit/rante, leot, terutama inghak dan reureueus, yang bersifat feminin. Sedangkan penembang wanita, pada bagian-bagian tertentu ia akan menggunakan keempat dongkari tersebut. Berkaitan dengan hal ini, Elis Rosliani (wawancara, 21 November 2012) mengemukakan bahwa apabila sedang mengajarkan lagu pada para siswanya di SMKN 10 (dulu SMKI), ia selalu memperingatkan para siswanya agar bagi pria sebaiknya tidak menggunakan beulit/rante, leot, terutama inghak dan reureueus, dalam menembangkan suatu lagu. Sebaliknya bagi wanita, selain menggunakan dongkari yang bersifat maskulin, juga sebaiknya menggunakan keempat dongkari tersebut.

Contoh kasus penggunaan dongkari maskulin dan feminin dapat ditemukan ketika seorang penembang membawakan sebuah lagu, misalnya lagu Mupu Kembang, Wani-wani, dan Eros.

Lagu Mupu Kembang adalah salah satu lagu wanda papantunan berlaras pelog. Berikut adalah lagu dimaksud yang ditulis lengkap dengan notasi dan dongkari yang biasa digunakan oleh para penembang.

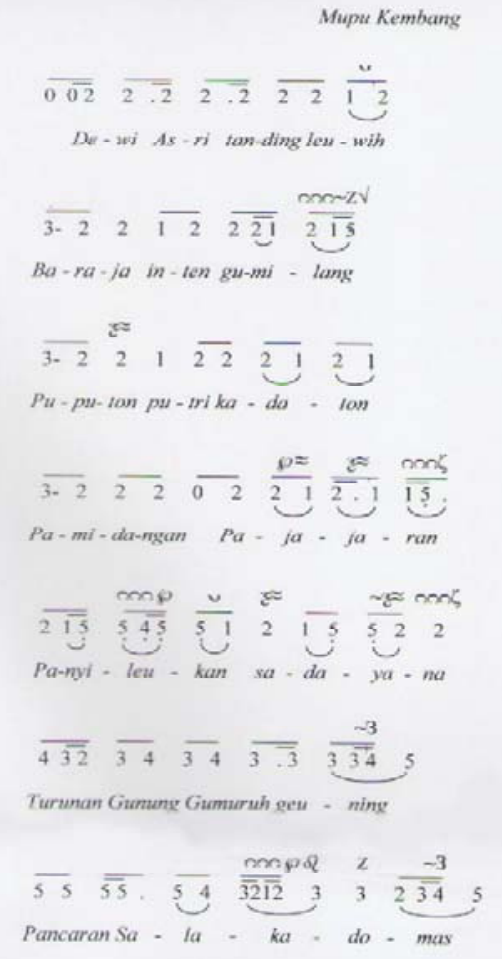

Di antara dongkari yang digunakan penembang dalam membawakan lagu Mupu Kembang terdapat dongkari feminin, yaitu: leot $(\checkmark)$, inghak ( ), dan beulit/rante ( $§)$. Leot digunakan pada suku kata terakhir, baris pertama: wih; dan pada suku kata keempat, baris kelima: kan. Inghak digunakan pada suku kata terakhir, baris kedua: lang; pada suku kata ketujuh, baris kelima: ya; pada suku kata terakhir, baris keenam: ning; dan pada suku kata terakhir, baris terakhir: mas. Beulit/rante digunakan pada suku kata keenam, baris keempat: ja; dan pada suku kata keenam, baris terakhir: $k a$.

Pada saat membawakan lagu Mupu Kembang, penembang wanita sudah biasa menggunakan ketiga dongkari tersebut pada suku-suku kata di atas dalam upayanya untuk dapat menjiwai lagu atau dapat membawakan lagu dengan ekspresif atau penuh penjiwaan. Demikian pula kemungkinannya untuk penembang pria, khususnya bagi penembang pria yang belum mengenal akan adanya perbedaan penggunaan ornamen bagi kedua penembang pria dan wanita. Akan tetapi bagi penembang pria yang sudah mengetahui, menyadari, serta dapat merasakan tentang adanya dongkari maskulin dan feminin, penembang pria ini akan berupaya untuk menghindari penggunaan ketiga dongkari feminin dimaksud dengan cara menggantinya dengan dongkari maskulin atau membawakan frase-frase kalimat lagu yang mengandung ketiga dongkari tersebut dengan cara yang berbeda.

Dalam menembangkan rumpaka baris kedua, misalnya, demi menghindari penggunaan inghak pada suku kata akhir (lang), penembang pria menembangkan baris kedua tanpa jeda (berhenti sejenak) pada akhir baris, tetapi langsung menggabungkannya dengan baris kedua, dan baru berhenti sejenak pada suku kata ton (puputon) pada baris ketiga. Dengan cara demikian, penembang pria tidak memiliki kesempatan untuk menggunakan inghak. Sebaliknya, 
penembang wanita biasa menembangkan baris kedua dengan berhenti sejenak pada akhir baris dengan tujuan agar memiliki kesempatan untuk menggunakan inghak yang dirangkaikan dengan dongkari sebelumnya (riak) dan dongkari sesudahnya (gedag dan jekluk).

Selain inghak, dalam lagu Mupu Kembang ini digunakan pula dongkari feminin lainnya, yaitu leot dan beulit/rante. Akan tetapi dalam lagu ini, kalaupun lagu tersebut dibawakan oleh penembang pria, kedua ornamen tersebut tidak lantas bisa diganti dengan ornamen maskulin. Jadi, penembang pria pun akan tetap menggunakan kedua dongkari feminin tersebut. Seperti telah dikatakan di muka, dongkari ini bersifat cross-gender, dongkari leot, inghak, beulit/rante, dan reureueus memang biasanya digunakan oleh penembang wanita, tetapi tidak tertutup kemungkinan dalam lagu-lagu tertentu, seperti halnya dalam lagu Mupu Kembang digunakan pula oleh penembang pria. Dalam lagu ini, dongkari feminin leot dan beulit/rante tetap saja harus digunakan oleh penembang pria. Di sini penembang pria tidak bisa menghindar untuk tidak menggunakan kedua dongkari tersebut atau menggantinya dengan dongkari lain, karena kantur (garis) melodi pada bagian itu menuntutnya demikian. Jadi, penggunaan dongkari feminin hanya boleh digunakan oleh penembang wanita atau oleh penembang wanita dan pria tidak seenaknya, tetapi bergantung pada kantur melodi yang menggunakan dongkari feminin tersebut.

Kasus di atas berbeda dengan kasus pada saat penembang membawakan lagu Wani-wani, laras pelog, yang lagu dan notasinya sebagaimana terlihat di bawah ini.

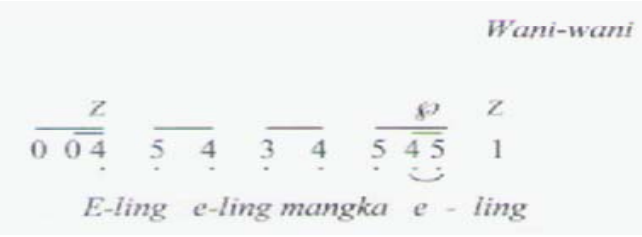

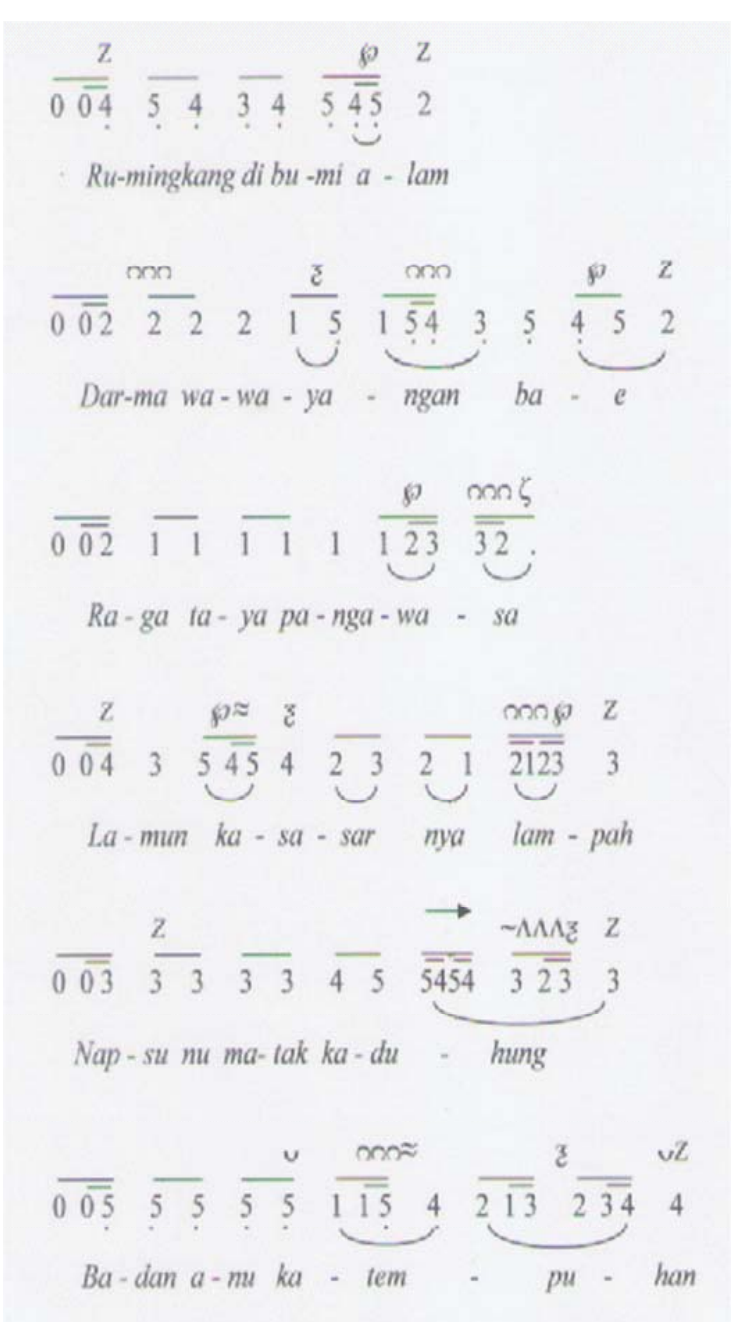

Berkaitan dengan dongkari pada pembawaan lagu Wani-wani, Elis Rosliani (wawancara, 21 November 2012) menceritakan pengalamannya ketika mengajar lagu tersebut kepada salah seorang siswa pria. Dalam menembangkan baris pertama: Eling-eling mangka eling, pada suku kata ketujuh (e), Elis biasa menggunakan gedag yang merupakan dongkari maskulin. Pada suatu waktu, siswa tersebut latihan bersama di rumah Neneng Dinar. Dalam latihan tersebut, Neneng Dinar mengajarkan dan menembangkan lagu Wani-wani baris pertama pada suku kata ketujuh (e) dengan menggunakan beulit yang merupakan dongkari feminin. Sehubungan dengan hal tersebut, siswa ini pun mengatakan kepada Elis Rosliani bahwa dalam menembangkan baris pertama pada suku kata ketujuh itu 
ia merasa lebih cocok menggunakan gedag yang memunculkan kesan gagah (maskulin, laki-laki) daripada menggunakan beulit yang terkesan halus (feminin, perempuan). Dari peristiwa ini dapat disimpulkan bahwa dalam menembangkan lagu Wani-wani baris pertama pada suku kata ketujuh untuk penembang pria lebih cocok menggunakan gedag daripada beulit, karena dongkari gedag dirasakan oleh penembangnya terkesan lebih gagah daripada dongkari beulit.

Dongkari gedag ini, selain "dipasanglawankan" dengan beulit, juga dengan reureueus yang masih merupakan dongkari feminin. Dalam menembangkan lagu, pada umumnya sering terjadi susunan penggunaan dongkari yang terdiri dari: inghakreureueus-jekluk. Penembang pria kemudian mengubah susunan penggunaan dongkari tersebut menjadi: gedag-jekluk. Untuk mencapai jekluk (karena jekluk tidak akan bisa dicapai tanpa penggunaan dongkari sebelumnya), di sini penembang pria menghilangkan (tidak menggunakan) inghak dan reureueus, kemudian menggantinya dengan gedag. Dengan demikian, ornamen yang digunakannya, yang terdiri dari gedag dan jekluk terkesan lebih gagah daripada ornamen yang digunakan oleh penembang wanita yang terdiri dari inghak, reureueus, dan jekluk. Contoh kasus ini misalnya terjadi pada saat menembangkan lagu Mupu Kembang baris kedua, suku kata terakhir lang (dari kata 'gumilang') seperti terlihat di bawah ini:

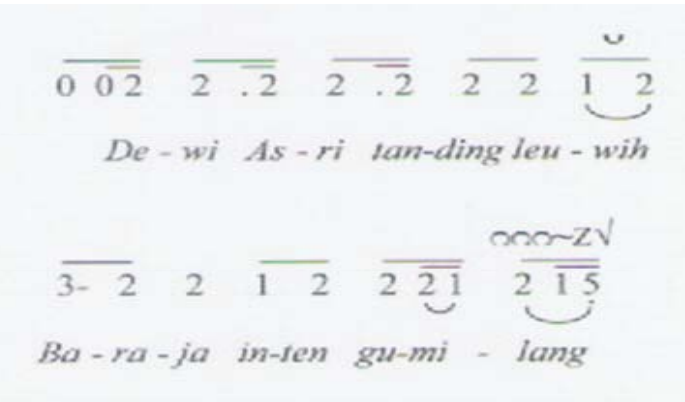

Dan seterusnya.........
Pada suku kata lang tersebut digunakan ornamen dengan susunan dongkari: riak-inghak-gedag-jekluk. Susunan dongkari tersebut sebenarnya bisa digunakan, baik oleh penembang pria maupun oleh penembang wanita. Akan tetapi pada kenyataannya, penembang pria dan wanita suka mengubah susunan dongkari tersebut atau menghilangkan satu atau dua dongkari untuk memunculkan kesan maskulin atau feminin dalam upaya mereka untuk mencapai penjiwaan lagu masing-masing. Penembang wanita biasanya menggunakan susunan tersebut tanpa gedag atau mengganti riak dengan reureueus, tetapi juga tanpa gedag. Sedangkan penembang pria akan menghilangkan riak dan inghak, yang digunakan hanya gedag dan jekluk.

Kasus selanjutnya mengenai penggunaan ornamen maskulin dan feminin ini tampak juga pada peristiwa pembawaan lagu Eros, terkait dengan penggunaan dongkari inghak dan leot. Berikut adalah lagu Eros, laras sorog, lengkap dengan notasinya.

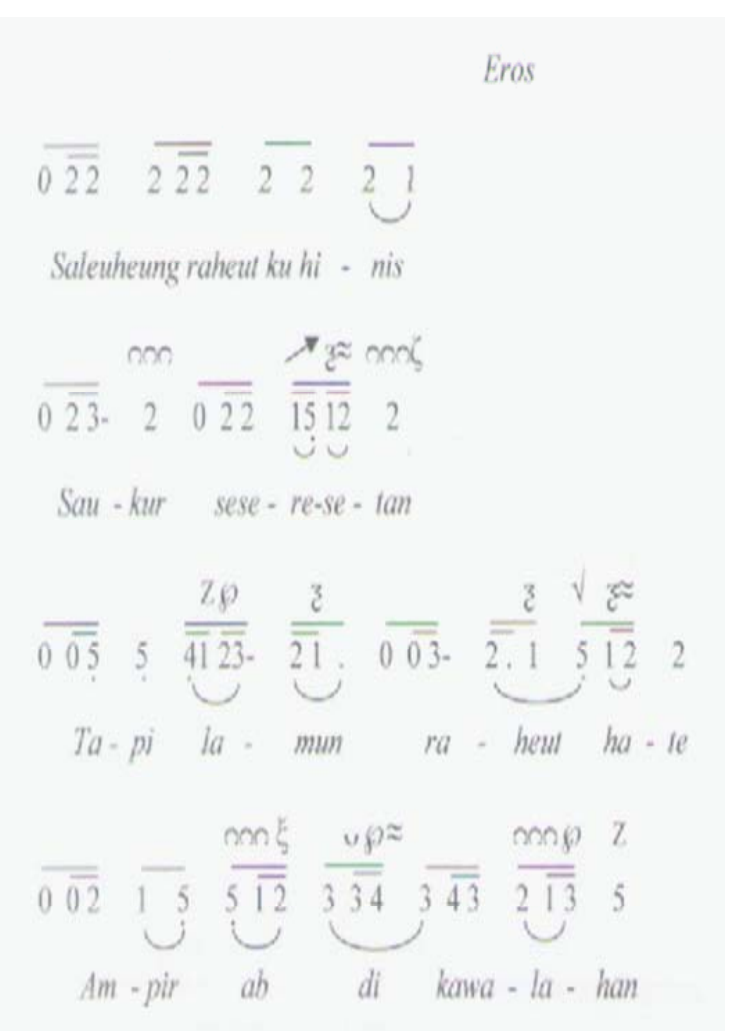




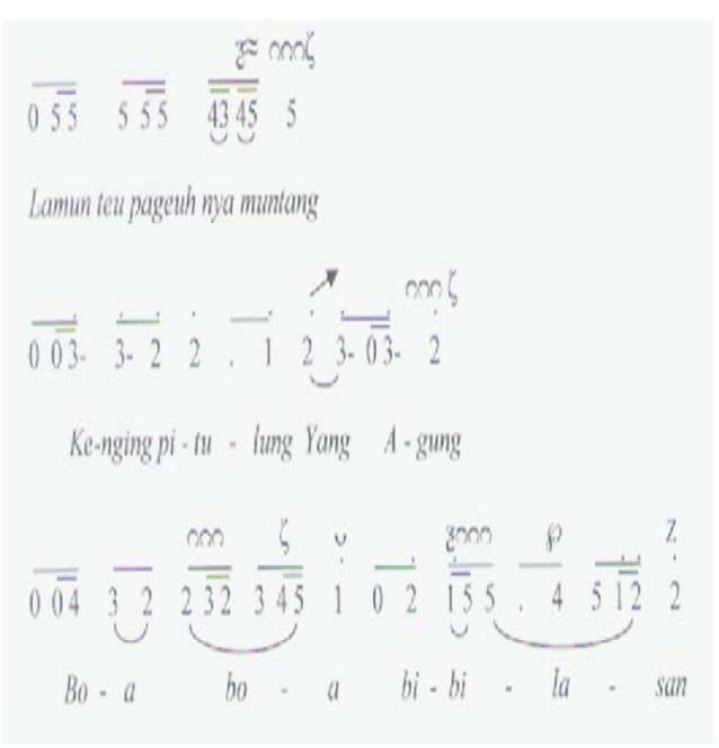

Lagu Eros terdiri dari dua versi. Versi pertama biasa dibawakan oleh penembang pria dan wanita, sedangkan versi kedua hanya biasa dibawakan oleh penembang wanita. Hal ini disebabkan oleh perbedaan kantur melodi pada baris-baris tertentu dan perbedaan penggunaan dongkari di antara keduanya.

Lagu Eros yang dinotasikan di atas adalah versi pertama, yang umum ditembangkan, baik oleh penembang pria maupun oleh penembang wanita. Di antara dongkari yang digunakan, terdapat dongkari feminin, yaitu: beulit/rante $(\varsigma)$ dan leot ( $v$ ). Beulit/rante terdapat pada: baris ketiga, suku kata ketiga; baris keempat, suku kata keempat dan ketujuh; dan baris terakhir, suku kata ketujuh; sedangkan leot terdapat pada baris keempat, suku kata keempat; dan pada baris terakhir, suku kata keempat.

Lagu Eros versi kedua sedikit berbeda dari lagu Eros versi pertama dalam hal melodi dan penggunaan ornamen/dongkari, terutama ornamen/dongkari feminin. Pada lagu Eros versi kedua, terdapat perubahan kantur melodi yang terjadi pada baris ketiga, mulai suku kata kelima: raheut hate; kemudian pada baris keempat: Ampir abdi kawalahan; dan pada baris terakhir, mulai suku kata pertama hingga suku kata keempat: Boa-boa.

Pada bagian-bagian rumpaka yang berubah ini, digunakan dongkari feminin, yaitu leot dan inghak. Leot digunakan pada baris ketiga, suku kata ketujuh: ha (dari hate); kemudian pada baris keempat, suku kata ketujuh; la (dari kawalahan); dan pada baris terakhir, suku kata ketujuh: la (dari bibilasan).

Untuk lebih jelasnya, perubahan kantur melodi dan dongkari yang terjadi pada lagu Eros versi kedua ini adalah sebagaimana terlihat pada perbandingan notasi bagian lagu Eros versi pertama dan kedua di bawah ini:

Baris Ketiga:

Versi pertama:

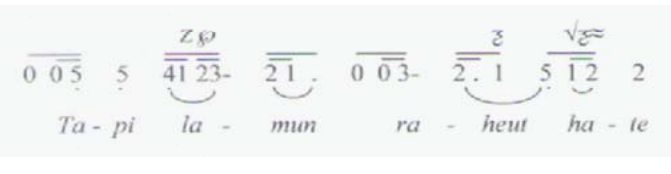

Versi kedua:

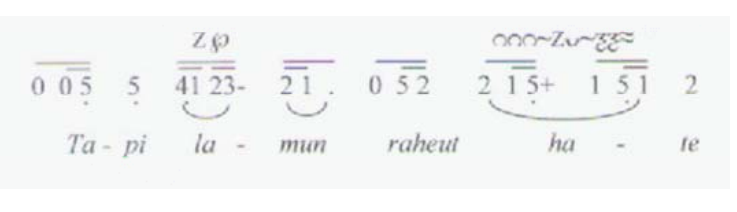

Baris keempat:

Versi pertama:

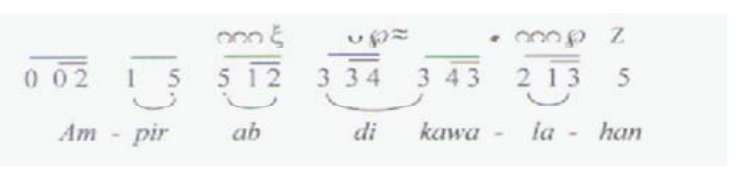

Versi kedua:

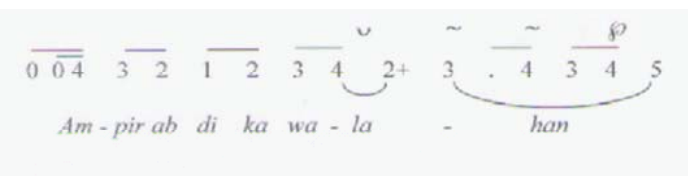

Baris terakhir:

Versi pertama:

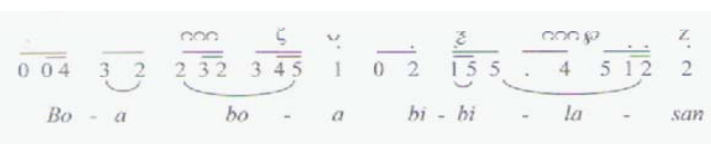


Versi kedua:

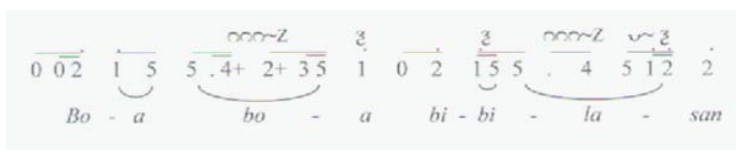

Perubahan kantur melodi pada bagian-bagian frase melodi dan penggantian dongkari feminin (leot dan inghak) pada suku-suku kata pada lagu versi kedua sebagimana telah diuraikan di atas memunculkan kesan feminin, perempuan, melankolis. Dengan kata lain, lagu versi kedua ini lebih cenderung memunculkan kesan feminin, sedangkan lagu versi pertama lebih cenderung memunculkan kesan maskulin. Oleh karena itu, pada saat membawakan lagu Eros, penembang pria biasa memilih versi pertama, sedangkan penembang wanita biasa memilih versi kedua.

Kendatipun demikian, sebagaimana telah dikemukakan, fenomena gender dalam ornamen lagu-lagu Tembang sunda cianjuran bersifat cross-gender. Dalam kaitannya dengan hal ini, A. Tjitjah, misalnya, saat menembangkan lagu Eros biasa menggunakan versi pertama yang bersifat maskulin, sedangkan Euis Komariah (alm.) biasa menggunakan versi kedua yang bersifat feminin (Elis Rosliani, wawancara, 21 November 2012).

\section{PENUTUP}

Dalam Tembang sunda cianjuran, fenomena (konsep) gender dapat ditemukan dalam ornamen/dongkari. Fenomena gender dalam ornamen/dongkari tersebut dalam perwujudannya ditunjukkan oleh adanya ornamen/dongkari yang bersifat maskulin dan feminin yang masing-masing biasa digunakan oleh penembang pria dan wanita dalam menembangkan lagu-lagu Tembang sunda cianjuran. Kendatipun demikian, hal tersebut tidak terlepas dari fenomena crossgender yang senantiasa hadir menyertainya sehingga dalam kasus-kasus tertentu, orna- men/dongkari yang bersifat maskulin bisa pula digunakan oleh penembang wanita; dan demikian pula sebaliknya.

Keterkaitan antara fenomena gender yang ditemukan dalam ornamen/dongkari dan penggunaannya oleh penembang pria dan wanita dalam praktik pertunjukan Tembang sunda cianjuran menunjukkan adanya saling keterkaitan dan saling memengaruhi antara ideologi gender yang melekat dalam kehidupan masyarakat Sunda dan pertunjukan musik-Tembang sunda cianjuran.

\section{Daftar Pustaka}

Ace Hasan Su'eb

1977 Wawasan Tembang Sunda. Bandung: CV Geger Sunten.

Apung Wiratmadja

1964 Sumbangsih kana Tembang Sunda. Bandung: Purnamasari.

1996 Kuring jeung Tembang (Pamanggih $\mathcal{E}$ Papanggihan). Bandung: Citra Mustika.

2007 Mengenal Seni Tembang Sunda. Bandung: CV Wahana Iptek Bandung.

2009 Salawé Sesebitan Hariring. Bandung: PT Kiblat Buku Utama.

Deni Hermawan

1994 "Gender Issues in Mythology, Symbolism and Performance of Tembang Sunda cianjuran in West Java, Indonesia: the Role of Female Instruments and Singers." 1 of 3 M.A. Papers. Washington: University of Washington, USA 
2002 Etnomusikologi: Beberapa Permasalahan dalam Musik Sunda. Bandung: STSI Press.

2006 “Membaca Potensi Tembang sunda cianjuran dalam Upaya Meningkatkan Pemahaman terhadap Nilai-nilai Budaya Sunda." Arena: Seni Pertunjukan Karya dan Karsa Budaya Bangsa, hlm. 24-42.

2014 "Gender dalam Tembang Sunda Cianjuran." Disertasi. Bandung: Universitas Padjadjaran.

Deni Hermawan dan H.M. Yusuf Wirdiredja 2006 "MPOS2E Vokal Tembang sunda cianjuran Berbasis Teknologi Multimedia." Bahan Ajar, P3AI STSI Bandung.

Denny R. Natamihardja

2009 Ngaguar Mamaos Cianjuran. Cianjur: Lembaga Kebudayaan Cianjur.

Elis Rosliani

1998 “Teknik Vokal A. Tjitjah dalam Tembang sunda cianjuran." Skripsi Sarjana STSI Bandung.

Enip Sukanda

1984 “Tembang sunda cianjuran: Sekitar Pembentukan dan Perkembangannya."Bandung: Proyek PengembangInstitut Kesenian Indonesia Subproyek Akademi Seni Tari Indonesia Bandung.

Koskoff, Ellen

1987 "An Introduction to Women, Music, and Culture." dalam Women and Mu- sic in Cross-Cultural Perspective, Ellen Koskoff, ed. Urbana and Chicago: University of Illinois Press.

M. Yusuf Wiradiredja, dkk.

2001 Tembang sunda cianjuran: Bahan Apresiasi Siswa SD dan SLTP di Kabupaten Cianjur. Cianjur: Kerja sama Dinas P \& K Kabupaten Cianjur dengan Jurusan Karawitan STSI Bandung.

Moore, Henrietta L.

1991 Feminism and Anthropology. Third Edition. Cambridge: Polity Press.

Rina Sarinah

1994 “Teknik Penyuaraan Tembang sunda cianjuran Wanda Papantunan dan Jejemplangan Bakang Abubakar." Skripsi Sarjana, STSI Surakarta.

William, Sean

1990 "The Urbanization of Tembang Sunda, an Aristrocratic Musical Genre of West Java." Ph.D. Dissertation, University of Washington.

Zanten, Willem van

1987 "Tembang Sunda: an Ethnomusicologi cal Study of the Cianjuran Music in West Java." Ph.D. Dissertation, University of Leiden.

1989 Sundanese Music in the Cianjuran Style. Holland: Foris Publication.

2008 "The Merriage Relationship between Player and Kacapi Zither in West Java." Ethnomusicology Forum, Vol. 17, No. 1, pp. 41-65. 